\title{
WHO IS THE THIRD PERSON? FLUID TRANSITIVITY IN MOJEÑO TRINITARIO ${ }^{1}$
}

\author{
FRANÇOISE ROSE \\ Laboratoire DynamiQue Du Langage, CNRS, AND Université Lyon 2
}

\begin{abstract}
Mojeño Trinitario shows a split-intransitivity system combined with a differential marking pattern for third-person A/S. The pronominal system of the A/S paradigm is quite complex. There are five markers for third person, specified for humanness, number, gender, and speaker's gender. Interestingly, these markers compete with another marker for third person, the prefix ty-, which is semantically unspecified. The most important factor in the distribution of the two alternatives for third-person A/S marking is transitivity. The transitivity of a construction cannot be determined just by the valence of the root (the number of participants) but depends also on other parameters such as the semantic characteristics of the participants and the discourse function of the utterance. As a consequence, transitivity must be seen as a continuum rather than a dichotomy. Since most roots are ambitransitive, transitivity is a category of the utterance level rather than the lexical level. This fluid transitivity is an essential characteristic of Mojeño Trinitario.

[KeYwords: Mojeño Trinitario, Arawak, transitivity, subject, third person]
\end{abstract}

"el prefijo ti-. . .es. . .una de las maravillas de las lenguas mojas"

(Olza Zubiri, Nuni de Chapi, and Tube 2002:528)

1. Introduction. The basic question addressed in this paper is: When does Mojeño Trinitario specify who is the third-person subject? In this language, a third-person subject is obligatorily indexed by a prefix on the verb. There are two options for indexing a third-person subject on the verb in Trinitario: (a) using one of the third-person markers that are informative about the semantic characteristics of the referent in terms of animacy, number, and gender ( $m a,-\tilde{n} i-, s-, t a-$, or $n a-)$ or (b) using the $t y$ - prefix, simply signaling that the subject argument is a third person.

The aim of this article is to discuss the distribution of the alternative options for third-person subject encoding, and the coherence of the overall system, framed around the central notion of fluid transitivity.

\footnotetext{
${ }^{1}$ Preliminary versions of this paper have been presented at the Research Centre for Linguistic Typology, La Trobe University, March 14, 2007, at the Workshop on Argument-Coding Systems in Bolivian Lowland Languages, held at the Centre d'Etudes des Langues Indigènes d'Amérique (CELIA), in Villejuif, April 5-7, 2007, and at the Atelier de Morphosyntaxe of the Dynamique du Langage (DDL) Laboratory in Lyon, on December 5, 2008. I wish to thank the participants at those meetings for questions and comments. I am also grateful to Antoine Guillaume, Knud Lambrecht, Mark Peake, Scott DeLancey, and an anonymous IJAL reviewer for their meticulous readings and comments.
}

[IJAL vol. 77, no. 4, October 2011, pp. 469-94]

(C) 2011 by The University of Chicago. All rights reserved.

0020-7071/2011/7704-0002\$10.00 
Section $\mathbf{2}$ gives a brief introduction to Mojeño Trinitario. Section $\mathbf{3}$ goes deeper into the pronominal system and presents the problematic third-person markers. The rest of the paper examines and analyzes the distribution of the alternative ways of indexing a third-person subject. Their distributions are first presented as complementary according to rules related to transitivity and the person of the object (4). The traditional view of transitivity as a dichotomy is then used to show that Mojeño Trinitario displays fluid transitivity, with many ambitransitive roots. Then constructions are presented (in 5) that suggest that the distribution of person prefixes is dependent on transitivity defined as a continuum rather than as a dichotomy (Hopper and Thompson 1980), with transitivity defined by valence but also other parameters (e.g., aspect, object affectedness). Moreover, the transitivity of a specific clause is correlated to its discourse function (foreground or background). Section 6 explains the remaining exceptions as responding to discourse factors. The conclusion summarizes the functions of the Trinitario differential third-person subject-marking system and compares this system to other Arawak indexation systems.

\section{Mojeño Trinitario.}

2.1. Sociolinguistics and documentation. Mojeño Trinitario is a dialect of Mojeño, one of the 20 indigenous languages still spoken in Amazonian Bolivia (Crevels 2002). Mojeño is one of the few South Arawak languages spoken in Bolivia, along with Baure and Paunaka (Danielsen 2007; and see also her paper in this volume). The Arawak family contains the largest number of languages in South America (40 living ones) spoken in 12 countries in Central and South America (Aikhenvald 1999). The Mojeño community (previously called Moxo) consists of four groups: Trinitario, Ignaciano, Loretano, and Javierano. The Trinitario dialect is exclusively spoken in the Beni Department, in the Territorio Indígena Parque Nacional Isiboro-Secure (TIPNIS), in the Territorio Indígena Multiétnico (TIM), along the Mamoré River, in and around the towns of Trinidad, San Lorenzo, and San Francisco de Moxos. The Mojeño population is over 32,000, with around 3,220 speakers of Trinitario and Ignaciano (Crevels and Muysken 2009). Trinitario and Ignaciano are endangered, while Javierano is moribund, with about five (semi-)speakers (Rose 2011), and Loretano is extinct.

Documentation of Mojeño can be found from the beginning of the eighteenth century (see Saito 2005), the best example of which is the Arte de la lengua moxa con su vocabulario y catecismo, of Father P. Marbán (1701). Linguistic works are richer for Ignaciano than for Trinitario, and to my knowledge are nonexistent for Loretano and Javierano. Ignaciano is described in a comprehensive grammar (Olza Zubiri, Nuni de Chapi, and Tube [henceforth Olza Zubiri et al.] 2002), a dictionary, and some S.I.L. studies (Ott and Ott $1967 a ; 1967 b ; 1983)$. An alphabet was proposed for Trinitario at a 1995 
workshop directed by Pilar Valenzuela and sponsored by the Bolivian Subsecretaría de Asuntos Etnicos of the Education Ministry and UNICEF. The final report from the workshop contained an alphabet booklet (Fabricano Noé, Semo Guají, and Olivio 2003). This writing system is used in this article. ${ }^{2}$ Descriptions of the language include a handbook and a dictionary (Gill 1957; 1970/1993), a master's thesis on Trinitario morphology (Salvatierra 2005), and a basic bilingual grammar by a group of speakers and teachers (Ibáñez Noza et al. 2007). ${ }^{3}$

I collected the data in this paper in the field, in Trinidad and San Lorenzo de Moxos, from September to October 2005, August to October 2006, and April to July 2008. The data are based primarily on five and a half hours of recordings of spontaneous (or semi-spontaneous ${ }^{4}$ ) discourse. Elicitation played a minor role in the data collection.

2.2. Typological overview. Trinitario is an agglutinating language, with a large number of suffix slots and a few prefix slots (1) (see Rose [forthcoming] for a morphological inventory). Lexical and grammatical morphemes display several surface forms, due to a rich system of morphophonemic rules and a pervasive process of vowel deletion (Rose 2008).

(1)

p-emtio-k-yore-wore ene wi-po
2SG-get.lost-ACT-FUT-REP and NEG-PERF
$n$ - $a$ - $k$-uch- $k u$-'-vi-yre
1SG-IRR-CAUS-go.out-CLAS-ACT-2SG-FUT ${ }^{5}$

'You are going to get lost again and this time, I will not take you out of it'.

${ }^{2}$ The Trinitario phonological inventory is given below, with the practical orthography (enclosed in angle brackets) specified where different from the IPA conventions (in virgules). Trinitario vowel phonemes are /i/, /e/, /a/, /o/, /u/, and the diphthong /əe/ <ae $>$, plus their long correspondents written by doubling the vowel, i.e., $\langle$ ii $>,<$ ee $>,<$ aa $>,<00\rangle,<$ uu $>$, and $<$ aee $>$. Trinitario consonant phonemes are the oral stops $/ \mathrm{p} /, / \mathrm{t} /, / \mathrm{c} /<\mathrm{ty}>, / \mathrm{k} /, / \mathrm{l} /<<^{\prime}>$, the nasals $/ \mathrm{m} /$, $/ \mathrm{n} /, / \mathrm{n} /<\tilde{\mathrm{n}}>$, the fricatives $/ \beta /<\mathrm{v}>, / \mathrm{s} /, / \mathrm{c} /<\mathrm{gi}, \mathrm{g}>, / \mathrm{x} /<\mathrm{j}>$, the affricates $/ \mathrm{ts} /$ and $/ / \mathrm{tg} /<\mathrm{ch}>$, the flap $/ \mathrm{r} /<\mathrm{r}>$, and the glides $/ \mathrm{w} /<\mathrm{w}, \mathrm{u}>$ and $/ \mathrm{j} /<\mathrm{y}, \mathrm{i}>$.

${ }^{3}$ Both grammars of Ignaciano (Olza Zubiri et al. 2002) and Trinitario (Gill 1957) are highquality works; however, they are not easy for linguists other than specialists of Mojeño to consult. The former gives pages of nonsegmented and unglossed examples, while the latter is designed as a pedagogical handbook with short vocabulary and grammar lessons built around made-up conversations, questions and answers, and exercises.

${ }^{4}$ Two of the texts are renderings of the Frog Story, a storybook made up of drawings only (Mayer 1969).

${ }^{5}$ The following abbreviations are used in this paper : ACT active; APPL applicative; ART article; CAUS causative; CLAS classifier; COP copula; DEM demonstrative; DIM diminutive; F feminine (singular); FUT future; INDET indeterminate; IRR irrealis; M masculine (singular); MID middle; NEG negation; NH nonhuman; NOMZ nominalizer; PAST past; PERF perfect; PL plural; PL.KIN plural 
Nominal phrases are remarkable for their high frequency of occurrence. The basic order of constituents is SVO (2). There is no nominal case. When a referent is introduced for the first time, it is usually introduced as a subject postposed to the verb. Given subject and object participants can be referred to by independent pronouns, usually preposed to the verb. ${ }^{6}$

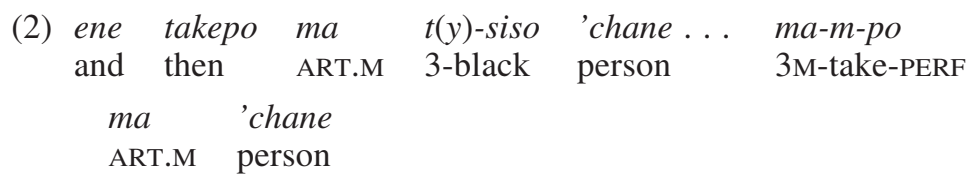

'And then the black man took the (lost) man'.

A common construction is the equative, where two NPs follow each other without a copula (3). Another construction with a pronoun fronted in focus and followed by a verb is somewhat comparable: the verb, often suffixed with a $-r i$ ' $i$ suffix, ${ }^{7}$ seems to be equated to the pronoun, as in (4).

$\begin{array}{ll}\text { (3) } \text { eto } & n \text {-emtone } \\ \text { PRO.NH } & 1 \mathrm{sG} \text {-work }\end{array}$

'This is my work'.

$\begin{array}{llll}\text { (4) } \text { eto } & n \text {-meto-ko-o'i } & \text { tata-noviono, } & \text { meme-noviono } \\ \text { PRO.NH } & \text { 1SG-Say-ACT-ri'i } & \text { father/Sir-PL.KIN } & \text { Mum/Mrs-PL.KIN }\end{array}$

'That is what I had to say, ladies and gentlemen'.

2.3. Trinitario indexation system. Predicates are obligatorily marked with at least one person prefix or suffix. Third-person suffixes are zero morphemes. Prefixes occur on intransitive verbs (active [5]) and stative [6]), referring to their unique argument. They also occur on transitive verbs (7), referring to their agentive argument. Note that the same paradigm (presented in 3 below) is used on nouns to refer to their possessor (8).

(5) $n$-ute-k-po

1SG-come-ACT-PERF

'I just came'.

(6) n-uuna

1sG-be.good

'I am good'.

for kinship terms; PL.o plural of the object; PLURACT pluractional; POSS possessed form of the noun; PREP preposition; PRO pronoun; REP repetitive; SAP speech-act participant; SG singular; VBZ verbalizer.

${ }^{6}$ In cases where the reference of the pronoun is ambiguous, a nominal phrase can be adjoined to the pronoun, and/or the pronoun is postposed to the verb.

${ }^{7}$ All of the functions of this suffix have not yet been investigated (thus it is not glossed). In most cases, it seems to be used to mark an equative construction. 
(7) n-echji-ko'e

1sG-talk.to-ACT-2PL

'I am talking to you'.

(8) n-ousa

1SG-village

'my village'

Suffixes index the patientive argument of a transitive verb (9) or the unique argument of both nominal predicates (10) and an extra class of stative intransitive predicates (11). ${ }^{8}$

(9) p-ewacho-k-a-nu

2SG-replace-ACT-IRR-1SG

'Replace me!'

(10) 'jiro-nu-po

man-1SG-PERF

'I was a man then'.

(11) juiti 'chosi-nu-po

now old-1SG-PERF

'Now I am old'.

There is a split in the alignment system: the argument of intransitive clauses is marked like an A on verbal predicates, while it is marked like an $\mathrm{O}$ with nonverbal predicates. If all types of predicates and not only verbs are taken into account, Trinitario displays a split-intransitivity alignment system, as defined by Merlan (1985), inter alia.

3. The pronominal system and third-person prefixes. Table 1 presents the pronominal paradigms used for argument encoding. From left to right are presented prefixes used on verbs and nouns, suffixes used on predicates, and free pronouns. Table 1 highlights the similarity of the pronominal paradigms, for which a unique diachronic source can be postulated. The different paradigms show few differences and are comparable in categorization and form. The first two columns consist of bound person indexes that are subject to a rich system of morphophonemic rules. ${ }^{9}$

3.1. Third-person affixes. The pronominal system is a wonderful embodiment of a saliency effect: the more salient the referent is, the more

\footnotetext{
${ }^{8}$ It is not clear whether this class should be considered nouns, verbs, or adjectives. They form descriptive predicates, including also some bodily processes. It is hard to tease them apart on semantic grounds from the class of nonagentive intransitive verbs.

${ }^{9}$ The morphophonemic rules concerning third-person prefixes are as follows. The specified $m a-, n a-$, and $t a-$ third-person prefixes undergo various morphophonemic processes. Their final
} 
TABLE 1

Some Trinitario Person Paradigms

\begin{tabular}{|c|c|c|c|}
\hline & Prefixes & Suffixes & Pronoun \\
\hline $1 \mathrm{sg}$ & $n-$ & $-n u$ & nuti \\
\hline $2 \mathrm{SG}$ & py- & $-v i$ & piti \\
\hline $1 \mathrm{PL}$ & $v y-$ & -(wok)ovi & viti \\
\hline $2 \mathrm{PL}$ & $a-$ & -'e & eti \\
\hline $\begin{array}{l}3 \mathrm{M} \\
\text { (Male } \\
\text { speaker) }\end{array}$ & $\begin{array}{l}\text { ma- } \\
(\sim m u-, m-)\end{array}$ & - & ema \\
\hline $\begin{array}{l}3 \mathrm{M} \\
\text { (Female } \\
\text { speaker) }\end{array}$ & $\begin{array}{l}\tilde{\boldsymbol{n}} \boldsymbol{i}- \\
(\sim \tilde{n}-)\end{array}$ & - & $e \tilde{n} i$ \\
\hline $3 \mathrm{~F}$ & $s-$ & - & esu \\
\hline 3PL & $\begin{array}{l}n a- \\
(\sim n-)\end{array}$ & $\begin{array}{l}-w o k o \\
(3 \mathrm{PL})\end{array}$ & eno \\
\hline $3 \mathrm{NH}$ & $\begin{array}{l}t a- \\
(\sim t-)\end{array}$ & & eto \\
\hline 3 & $\begin{array}{l}\text { ty- (on verbs only) } \\
\left(\sim t^{-}\right)\end{array}$ & & \\
\hline
\end{tabular}

finely the index will define it semantically. Within the third person, the basic distinction lies between nonhuman and human referents. The nonhuman category is not further refined. Within human, number distinguishes singular versus plural, the latter not being further categorized. Within singular human, a gender distinction is made. The feminine is categorized as such, while the masculine exhibits two categories according to the gender of the speaker. ${ }^{10}$ Thus human singular masculine referents involve a form with a heavy semantic load, while - at the other extreme of the saliency scalenonhumans are referred to with a form with a minimal semantic load that neutralizes distinctions of gender, number, and gender of the speaker.

3.2. The third-person $t y$ - prefix. Beside this series of third-person indexes found in all pronominal paradigms (also including demonstrative formatives and articles), an extra marker for third person is found exclusively in the paradigm of person prefixes with verbs (first column of table 1). This ty- $(\sim t-)$ prefix is an underspecified third-person marker. It distinguishes neither humanness, nor number, nor gender of the referents or of the speaker, as illustrated in the different translations of (12) and (13). (13) also has the suffix -ono (realized as $-m$ ), used on verbs to indicate the

$/ \mathrm{a} /$ is deleted when preceding vowels $/ \mathrm{a}, \mathrm{o}, \mathrm{u} /$. The sequences mue $[\mathrm{mw} \varepsilon]$ and tae-, nae- [təe-, nəe-] are created when $m a-, t a-$, and $n a-$ precede $/ \mathrm{i}, \mathrm{e} /$. The vowel of the $\tilde{n} i$ - prefix is deleted preceding any vowel. The ty-prefix is realized /t/ in front of the palatal vowels /i, e/ and all of the consonants except $/ \mathrm{x} /<\mathrm{j}>$.

${ }^{10}$ The glosses of pronominal forms are simplified in that M or F imply HUMAN and SINGULAR, and PL implies Human. Gender of the speaker is not specified in the M gloss. 
plurality of S or A uniquely in conjunction with the ty-prefix. It is likewise found on nouns to express plurality.

(12) $\boldsymbol{t}(\boldsymbol{y})$-ерепо-ро

3-die-PERF

'He/she/it died'.

(13) $t(y)$-epeno-m-po

3-die-PL-PERF

'They died'.

Synchronically, the $t y$ - prefix is realized /t/ preceding the palatal vowels /i, e/ and all the consonants except $/ \mathrm{x} /<\mathrm{j}>$. Preceding the vowels /a, o, u/ and $/ \mathrm{x} /<\mathrm{j}>$, it is realized as a palatal occlusive [c], transcribed $<\mathrm{ty}>$ in the orthography. This is important since both the underspecified ty-prefix and the specified $t a$ - prefix can surface as /t/ (see n. 9). For this reason, these prefixes are written $t(y)$ - and $t(a)$ - in the first line of the examples when they are realized as $/ \mathrm{t} /$. Neither the form nor the category that $t y$ - expresses (thirdperson unspecified) can be traced back to Proto-Arawak (Payne 1987). Only two geographically close Arawak languages (Paunaka and Baure) also display a $t i$ - prefix, though with a somewhat different distribution (see Danielsen's paper in this volume).

In the rest of this article I investigate and compare the distribution of $t y$ - and the $m a-, \tilde{n} i-, s^{-}, t a-, n a-$ forms. How does an underspecified form coexist in the same domain with a series of specified forms? Why would a language have developed such a marker? The alternative encoding of thirdperson arguments is restricted to the prefix position on verbs, to refer to the subject $\left(\mathrm{S}_{\mathrm{a}} / \mathrm{A}\right)$ of an intransitive or a transitive verb. The aim of this paper is to explain this differential marking for S/A, by determining which form (unspecified or specified) is used when a third-person subject is indexed on a verb. It seeks to explain the coherence of such a system, and consequently the rationale for having these two options.

This point is crucial for the Mojeño language: "All the grammarians that have studied the Mojo languages have come across the difficult point of the ty- prefix" (Olza Zubiri et al. 2002:523 [my translation]). In the Gramática Moja Ignaciana (Olza Zubiri et al. 2002), two chapters are devoted to the topic, yet the main author is not completely confident about the analysis. The Trinitario Grammar (Gill 1957) addresses the question briefly (1957:75-76), but explains it in a way "not only divergent, but contrary to" Olza's analysis (Olza Zubiri et al. 2002:527 [my translation]). It should be noted that the Ignaciano and Trinitario dialects are comparable in the domain investigated in this paper. Two main divergences are the indexing behavior of deverbal nouns and the fact that in Ignaciano, the $t i$ - prefix is optional on consonantinitial roots (Olza Zubiri et al. 2002:478). This disagreement between these specialists on Mojeño morphosyntax is evidence of how challenging this 
differential third-person subject marking is. My goal is to offer a coherent explanation of the problem. Both the works cited above have been of great help in confirming, challenging, and refining my intuitions.

\section{Differential S/A marking: general rules related to the transitiv-} ity of the verb and the person of the object. The general rules stated below describe the basic distribution of third-person prefixes (ma-, $\tilde{n} i-, s-$, ta-, $n a-v s . t y-)$ according to verbal transitivity and the person of its object. They predict the correct form of the third-person subject index (given in boldface in the examples), except for some constructions that are presented in 5 and $\mathbf{6}$ below.

A marker of the $m a,-\tilde{n} i-, s-, t a-, n a-$ set (abbreviated as the $m a-$ set) is used to express a third-person subject on transitive verbs with a third-person object (14) or a complement clause in object position (15). The index defines the subject in terms of animacy, gender, and number. Recall that there is no suffix form for third-person object.

$m a$-transitiveV $(\mathrm{O} 3)$

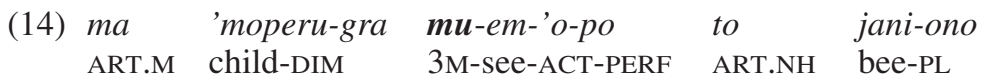

'The little boy saw the bees'.
$\begin{array}{lll}\text { ta-komnu } & \text { to } & \text { v-ipruj-ch- } a \\ \text { 3NH-need } & \text { ART.NH } & \text { 1PL-cure-ACT-IRR }\end{array}$
'The animals need to be cured' (lit., 'They [nonhumans] need that we cure them').

The $t y$-prefix is used for a third-person subject on intransitive verbs (active [16], stative [17]) and on transitive verbs with a SAP object, itself indexed on the verb with a suffix (18).

ty-intransitiveV

(16) $\boldsymbol{t}(\mathbf{y})-$ yom-po

3-go-PERF

'He/she/it/they went'.

(17) ty-uиnanaji s-omuire

3-be.beautiful 3F-also

'She is also beautiful'.

ty-transitiveV-1/2

(18) ty-okpo-wokovi

3-meet-1PL

'He/she/it/they meet us'. 
Basically, indexes of the $m a$ - set are used when two non-SAPs, i.e., two third persons, are involved. They play a disambiguating role, specifying some characteristics of one of the third persons, the subject. The ty-prefix is used in all other contexts. This means ty-is normally the only index to mark a third-person $\mathrm{S}$ on an intransitive verb.

Ditransitive verbs follow the same rule as transitive verbs, their subject indexation depending on the person of the object. They take a prefix from the $m a$ - set if the subject and objects are third persons (19), but take the ty-prefix if the suffixed object is a SAP (referencing the recipient) (20). What matters is the coexistence of two participants (always human in my corpus) as agent and recipient. ${ }^{11}$ When both human participants are third person, then the $m a$ - set is used to specify characteristics of the subject. Otherwise, when the recipient is a speech-act participant, i.e., identified without ambiguity in the speech situation, the third-person subject is referred to with the unspecified ty-.

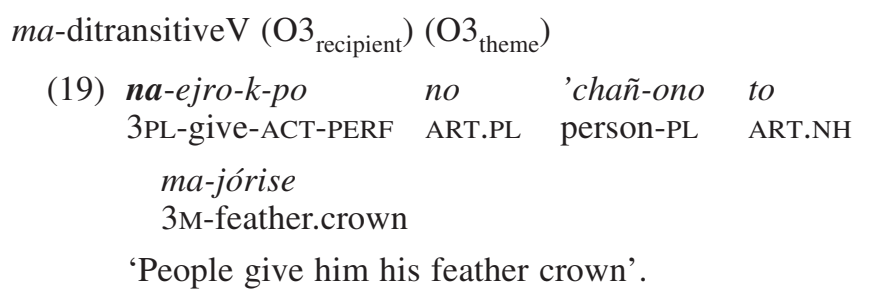

'He gives us medicine'.

An important point to note is that, in order to assign the correct person index to a root, its transitivity has to be determined in the discourse context, taking into account first that transitivity is not assigned to lexical roots (many are ambitransitive) and second valency-changing derivations.

4.1. Ambitransitivity. Agentive ambitransitivity is common in Mojeño Trinitario, as many verbal roots can, without morphological change, be used transitively or intransitively, i.e., without an object, their unique argument representing the agent. Ambitransitive roots are cross-referenced in discourse according to their transitivity in the context of the utterance. (21) shows, in the same utterance of a text, both uses of the same verbal root, first without an object, second with a specific object.

\footnotetext{
${ }^{11}$ My data do not provide any example of first- or second-person themes in a ditransitive construction.
} 
(21)
ene $\boldsymbol{t}(\boldsymbol{y})-e u-k o-m-p o$,
and 3-SOW-ACT-PL-PERF
na-eu-ko-po
to
arusu

'And they start to sow, they sow rice'.

Ambitransitivity is striking when eliciting vocabulary. Elicitation of isolated verb forms regularly results in verb forms prefixed with ty- (without any overt object in the case of semantically transitive roots, as in 23).

(22) ty-jopu

3-be.white

'He is white' (but also 'she/it/they is/are white').

(23) ema t(y)-echji-ko

PRO.M 3-speak-ACT

'He speaks'.

When asked, speakers accept a specified third-person prefix on some verbs, those that are ambitransitive. The specified third-person prefix is used in the transitive construction, and the translation suggested by speakers contains an overt object (24). Speakers are nevertheless reluctant to utter an intransitive verb with a specified third-person prefix out of context, as (25) shows, although in 6.2 I examine a spontaneous example from a text.

(24) ema mu-echjiko

PRO.M 3M-speak-ACT

'He speaks to him'.

(25) *ta-jopu

3NH-be.white

'It is white'.

4.2. Valency-changing derivations. Trinitario displays many valencychanging devices. Detransitivized roots are cross-referenced like intransitive verbs and transitivized roots (with causative or applicative) like transitive ones. Once again, transitivity in discourse is what matters. In (26) below, the first verb is intransitive and thus its third-person subject is crossreferenced with ty-. The second verb is transitive with a third-person object (unexpressed); its third-person subject is cross-referenced with a specified index ( $t a$ - because the dog is "nonhuman"). The third verb is the middle form of a transitive root and takes $t y$ - for its third-person subject like any intransitive verb form. (27) shows the intransitive verb root júnopo 'to run' twice, with the same subject 'the dog' given in the preceding stretch of discourse. On the first occurrence, the third-person subject is indexed with $t y$-, since the verb is intransitive, and on the second with the specific nonhuman third-person subject index $t a$-, since the verb is transitivized through causativization. 
TABLE 2

General Rules in the Distribution of ty- versus $m a-, \tilde{n} i-, s$, $n a-$, AND $t a-$ ON VERBS

\begin{tabular}{lll}
\hline \hline Prefix & Root & Suffix \\
\hline$t y-$ & Intransitive & \\
$m a-$ set & Transitive & \\
$t y-$ & Transitive & $-1 / 2$ \\
$m a-$ set & Ditransitive & \\
$t y-$ & Ditransitive & $-1 / 2$ (recipient) \\
\hline
\end{tabular}

(26)

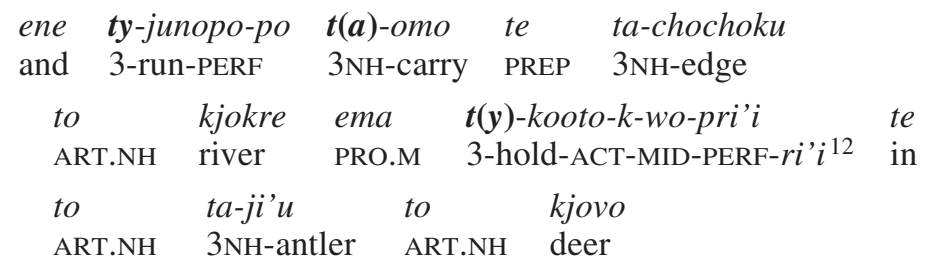

'and (the deer) ran and took him (the boy) to the riverbank, he (the boy) held (himself) on to the deer's antlers'

(27)

ene ty-uch-ko-po te theko ty-júnopo.
and 3-go.out-ACT-PERF to outside
3-run
ta-em-júnopo eto
3NH-SOC.CAUS-run PRO.NH

'And it (the dog) ran out. It was running with it (a pot on its head)'.

To summarize, the general rules stated in this section are based on both the transitivity of the verb form (in discourse and after valency-changing derivation) and the person of the object. They are summarized in table 2. Basically, the $m a$ - set is used for a third-person subject when the object is a third person (there is no suffix for third-person object). It specifies characteristics of the subject, helping to disambiguate the identity of the participants. Third-person subjects are indexed indifferently with ty-in all other situations, i.e., on intransitive verbs and on transitive verbs with a first- or second-person object.

\section{Differential S/A marking: particular cases related to the con-} tinuum of transitivity. Beside the rules stated above, some extra rules apply to a few constructions. Descriptions of these by Olza or Gill were helpful in consolidating my analyses. ${ }^{13}$ In the following cases, the relative

${ }^{12}$ For a better understanding of this suffix, see n. 7.

${ }^{13}$ Only in complement clauses-which, according to Olza Zubiri et al. (2002:495-500), trigger the $t i$ - indexation in Ignaciano_-do the Trinitario data differ from Olza's description of particular cases in Ignaciano. Verbs in complement clauses are indexed just like any independent verb in Trinitario. 
distribution of $m a-, \tilde{n} i^{-}, s^{-}, n a-$, and $t a-$ versus $t y$ - does not strictly follow the distribution based on valency and the person of the object. The selection of a marker of the $m a$ - set or ty-depends on further parameters, most of which are related to the continuum of transitivity, as introduced in Hopper and Thompson (1980).

5.1. Indefinite object. This parameter is not mentioned by Olza or Gill but corresponds to the "individuation of O" in Hopper and Thompson (1980). Most often this parameter results in differential object marking cross-linguistically, but in Trinitario it results in differential subject marking, as in (28). (29) shows that a verb with an indefinite object obligatorily encodes a third-person subject with ty-. An indefinite NP can basically be defined by the absence of the article.

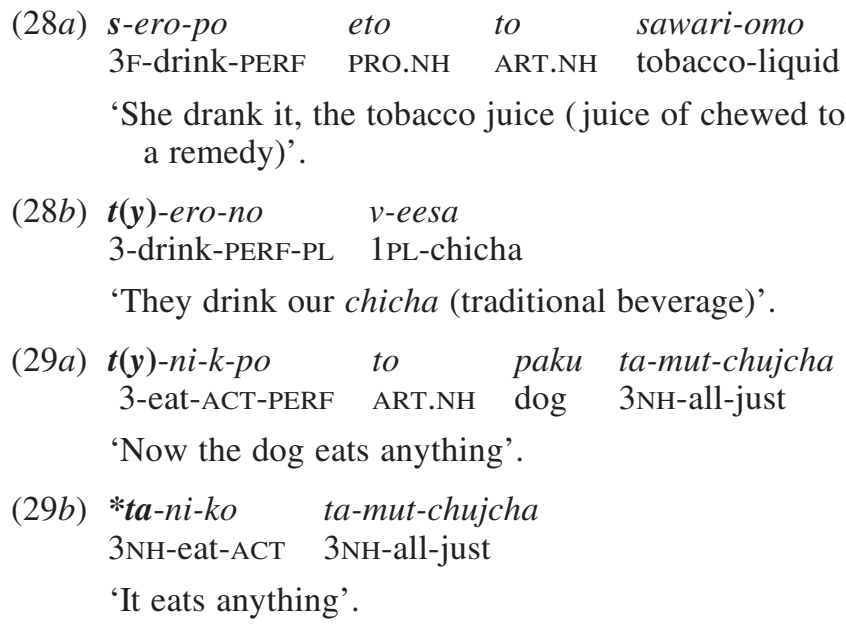

5.2. Negative subject. Another parameter corresponds in some way to what Hopper and Thompson call "affirmation." While negative sentences obey the general rules, a negative subject triggers a ty- cross-reference marker, even on a transitive verb with a third-person object, as in (30) and (31). ${ }^{14}$ This case is identified by Olza Zubiri et al. (2002:512-16) for Ignaciano.
naj-na-eji
ty-jikp-a
3PL.INDET-IRR-HSY
3-answer-IRR
'No one answered him'.

${ }^{14}$ Surprisingly, Olza states the opposite: "the verb following najina . . . would always carry a specified index for third person" (Olza Zubiri et al. 2002:512-16 [my translation]). Some examples he offers contradict his assertion. 


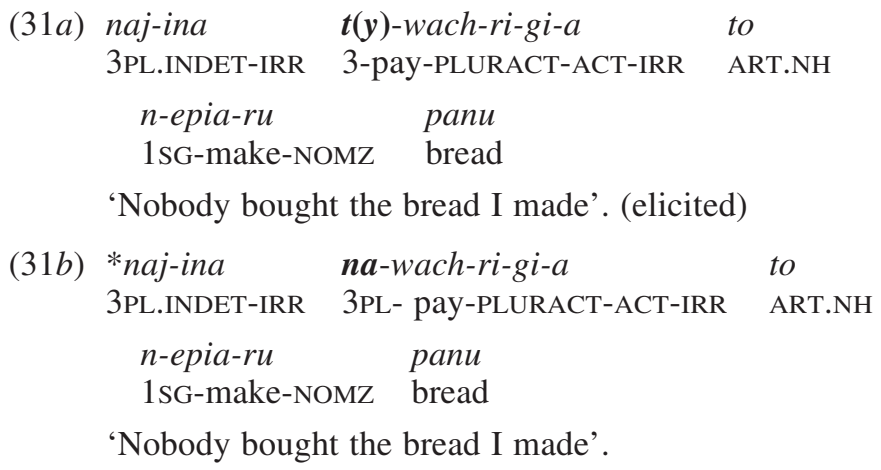

5.3. Denominal verbs. Word-class-changing derivations are common in Trinitario. Among these, $k o-\left(\sim k^{-}\right)$is a verbalizer with a proprietive (vBZ-cart 'to have a cart'), manipulative (vBZ-pot 'to cook), or causative (vBZ-plantation 'to cultivate') meaning. Denominal verbs formed with $k o$ - typically take ty- to refer to a third-person subject, even when they apparently govern a second argument, as in (32) and (33). ${ }^{15}$ On the whole, it seems they are extended intransitive predicates.

\section{t(y)-k-ijare Bernardo Noza Tamo 3-vBZ-name Bernardo Noza Tamo}

'His name is Bernardo Noza Tamo' (he has-a-name Bernardo Noza Tamo).

(33) movera 'chane-ni t(y)-ko-i'-ono confirmancion ${ }^{16}$ many person-PAST 3-VBZ-POSS-PL confirmation 'Many people had their confirmation'.

However, some ko- denominal verbs like kochane 'accompany', built on 'chane 'person', take the specified set of third-person subject indexes.

$$
\begin{aligned}
& \text { ene ty-utsaru ma-ko-chane to pak-gira } \\
& \text { and 3-play 3M-VBZ-person ART.NH dog-DIM }
\end{aligned}
$$

'And he plays in the company of the little dog'.

I propose that while most ko- denominal verbs are extended intransitives, some are lexicalized as transitive predicates, as with kochane. This is obvious from its use with a SAP object, as in the elicited example in (35). The semantic result is also somewhat different, offering further evidence for the

${ }^{15}$ Olza holds this as a rule for the Ignaciano dialect, even though some examples he gives show a specified index for a third-person subject (Olza Zubiri et al. 2002:874-82).

${ }^{16}$ This is the way an older speaker, who knows little Spanish, pronounced the Spanish word confirmación. 
lexicalization hypothesis. ${ }^{17}$ Note also that in this example, contrary to what occurs with most ko- denominal verbs, since both participants are necessarily animate, a device for participant disambiguation may be crucial.

(35) n-ko-chane-vi

1sG-VBZ-person-2sG

'I accompanied you'.

(elicited)

Cases of ambitransitivity are also noted among ko- denominal verbs; compare (36a) and (36b).

$\begin{array}{ll}\text { (36a) ema } & t(y) \text { - } k \text {-emtone } \\ \text { PRO.M } & 3 \text {-VBZ-work }\end{array}$

'He works'.

(elicited)

$\begin{array}{lllll}\text { (36b) ene eto } & \text { ma-k-emtone } & \text { ma } & \text { 'chane } \\ \text { and } & \text { PRO.NH } & 3 \mathrm{M} \text {-VBZ-work } & \text { ART.M } & \text { person }\end{array}$

'And this is what the man is working at'.

Denominal verbs again show that the distinction between intransitive and transitive verbs is not clear-cut, as some share characteristics of both categories (two arguments, but intransitive indexation). Again, Trinitario is characterized by fluid transitivity. In line with Hopper and Thompson (1980), this can be explained by the fact that most of these verbs do not express actions in the way that prototypical transitive verbs do.

5.4. Optative. Verbs in the optative mood take a specified prefix for their third-person subject, whatever their transitivity. This was first stated by Olza Zubiri et al. (2002:492-95) for Ignaciano and by Gill (1957:68) for Trinitario. Thus intransitive verbs and transitive verbs with a SAP object mark their subject with the $m a$ - set when in an optative clause. Optative clauses are moreover marked with the irrealis mood marker $a$ (suffixed in most cases, rarely prefixed). (37) shows that both an intransitive and a transitive verb with a first-person object use a $m a$ - prefix for their thirdperson masculine subject, whereas ty- would be expected if the sentence were not optative. (38) is evidence that the use of the $m a$ - set is triggered by the optative rather than by the irrealis marker. The irrealis is present on both occurrences of the same verb. In the first clause, jointly with the use of a $m a$ - set prefix, it expresses the optative. In the second clause, the irrealis triggers a temporal interpretation (not an optative one) and, subsequently,

${ }^{17}$ A further hypothesis would be that denominal verbs for which the second argument is preferably human were first lexicalized into transitive verbs. This would need to be tested on more examples. 
the intransitive verb is indexed regularly, with a ty-prefix for its thirdperson subject.
ma-te-gi-a
te pjoka,
mu-em-ojn-a-nu.
$3 \mathrm{M}$-come-ACT-IRR in DEM.NH 3M-see-REP-IRR-1SG

'Let him come here, let him come to see me'.
ene ma-siop-a te pjoka. t(y)-sióp-a-po,...
and 3M-enter-IRR in DEM.NH 3-enter-IRR-PERF

'Let him enter here. When he enters, ...'

A negative optative marked with $k u$ - also triggers subject indexation with a specified index, whatever the transitivity of the verb (see Gill 1957:88). (39) shows a specified third-person plural index on an intransitive verb in the negative optative mood.
py-joch-a
to
tapajo puejchu
na-ku-siopo
2SG-shut-IRR
ART.NH door
in.order.to
3PL-NEG.IRR-enter
'Shut the door not to let them enter'.

The same effect is triggered by the apprehensive construction marked with wich $u$ and the irrealis mood. It requires the specified set of indexes for a thirdperson subject. (40) shows a transitive verb with a first-person plural object displaying the specified non-human subject index.
(40) v-yan-a-po-ro
wichu ta-ni-gi-a-wokovi
spugi-ono
1PL-go-IRR-PERF-then lest 3NH-eat-ACT-IRR-1PL vulture-PL
'Then let's go lest the vultures eat us'.

The effect of the optative on Trinitario S/A marking is counterintuitive. Hopper and Thompson see the irrealis mood as a parameter for lower transitivity, while in Trinitario the optative mood triggers specific third-person subject encoding, which is a rather "transitive" marking. The explanation likely lies beyond the realm of transitivity.

5.5. Irregular verbs. A few verbs do not follow the general rules but encode third-person subjects exclusively with the specified third-person prefixes, whether they have an object or not. These include nosi 'stay, keep on', tupiru 'go straight', ke ko'e 'be so', koyemo 'happen to', jicho 'make, say', and less regularly ou'o ouriko 'be at, live'. In (41), the verb jicho carries a specified third-person index, although it is transitive with a firstperson object suffix, a configuration where ty- would normally be expected.

$$
\begin{array}{lllll}
\text { u-niko } & \text { ta-mutu, } \quad \text { ma-jicho-u-ri'i } \quad \text { ema } & \text { Viya } \\
\text { 1.PL-eat } & \text { 3NH-all } & \text { 3M-make-1PL-ri'i } & \text { PRO.M } & \text { Lord } \\
\text { 'We eat everything, the Lord made us that way'. } &
\end{array}
$$


In this section, five cases have been presented where the third-person subject encoding does not follow the general rules governing the distribution of tyvs. $m a$ - based on a strict definition of transitivity in terms of valence and the person of the object. In some constructions, ty- is used where the $m a$ - set is expected, and this seems to be systematically correlated with low transitivity on a transitivity continuum: indefinite object, negative subject, denominal verbs. Finally, the optative construction and some irregular verbs systematically use the $m a$ - set, even when $t y$ - is expected. This has been left unexplained for the time being.

6. Differential S/A marking: deviations on discourse grounds. Beside the constructions presented in $\mathbf{5}$ above, the general rules stated in $\mathbf{4}$ are violated in a few cases. Both of the following configurations are observed: ty- occurs where a specified third-person prefix is expected or, more rarely, a specified prefix occurs instead of ty-. These exceptions seem to be triggered by discourse factors.

In a randomly selected text 15 minutes long, the selection of the 220 thirdperson prefixes was classified according to the type of rule it obeys, in order to account for the relative importance of the rules and the exceptions. The text under study is expository, a talk by Leonardo Jou Ichu on how to prepare a new field. This explains the absence of first and second person and of the optative mood. What stands out is that valence and the person of the object (4) account for most of the cases $(63 \%)$. The rules more or less related to the continuum of transitivity (5) account for another large set of cases (26\%), which means that the rules presented thus far account for $89 \%$ of all cases. This suggests that transitivity is the key to third-person subject encoding. If we leave aside the ten forms that I am not able to account for, 14 cases of deviations to the rules remain, ten with $t y$ - and four with the $m a$ - set. The remainder of this section focuses on such exceptions (drawn from the whole corpus) and offers tentative explanations on discursive grounds.

I showed in $\mathbf{4}$ and $\mathbf{5}$ above that a third-person subject could be encoded on the same root by either the unspecified ty- or a specified prefix, according to the transitivity of the construction. Transitivity depends on morphosyntactic and semantic features, such as valence, person, or definiteness. However, elicited and text data show that the same clause can in some circumstances accept either marking, as illustrated by the elicited variants of (42) and the text examples in (43). Since this obviously cannot be accounted for on formal grounds, the explanation must be sought in the domain of pragmatics, i.e., in discourse. ${ }^{18}$

${ }^{18}$ More rarely, alternative subject encoding triggers differences in verbal meaning, perhaps in some way related to ambitransitivity or as a result of lexicalization. 
$\begin{array}{clll}\text { (42a)ema } & \boldsymbol{t}(\boldsymbol{y}) \text {-ko-pkare-ko } & \text { to } & \text { teja } \\ \text { PRO.M } & \text { 3-VBZ-fall-ACT } & \text { ART.NH } & \text { tile }\end{array}$

'He dropped the tile'.

(elicited)

(42b)ema ma-ko-pkare-ko to teja

PRO.M 3M-VBZ-fall-ACT ART.NH tile

'He dropped the tile'.

(elicited)

(43a) $m a$

$\begin{array}{lll}m a & \text { 'chane } & \boldsymbol{t}(\boldsymbol{y}) \text {-emtio- } k \text {-ri' } i \\ \text { ART.M } & \text { person } & \text { 3-get.lost-ACT-ri'i }\end{array}$

'the lost man'

(43b) ma 'chane mu-emtio-o-ri'i

ART.M person 3M-get.lost-MID-ri'i

'the lost man'

Gill's description of the Trinitario indexation system, based on contrastive out-of-context examples, mentions pragmatic factors in the distribution of third-person prefixes:

When the variation form of the subject prefixes [ $m a^{-}, s_{-}^{-}, \tilde{n} i^{-}, n a_{-}^{-}$, or $\left.t a^{-}\right]$is used, it indicates that the object of the verb (stated or unstated) is being emphasized.

In contrast, the $\mathrm{t}$ (or ti) $[t y$ - $]$ indicates that the subject of the verb is receiving the emphasis.

Ema tnico to cujpa. He ate the yuca.

But with the variation form:

Ema manico to cujpa. He ate the yuca.

[....]

Eno t-semono. They are angry.

But:

Eno nasemo. They are angry (at her, it, them, etc.). (Gill 1957:75)

Gill explains the alternation of indexation patterns in terms of EMPHASIS. This term is not developed, but the translations of the examples (and the underlining) suggest focalization of the contrastive focus type. The use of ty-would be correlated with subject focalization, and the use of the $m a$-set would be correlated with object focalization. This analysis is difficult to adopt without a precise analysis of discourse data. Artificial examples are not convincingly informative on pragmatic functions and pattern frequency.

It is interesting to note that Olza's analysis of Ignaciano is the opposite. The author considers $t i-$, the cognate of Trinitario $t y$-, to be the unmarked default element, used in discourse to signal topic continuity: "The $t i$ prefix is a 'low profile' prefix, a 'cold' or 'discreet' prefix, it doesn't stand out, is not contrastive, is used for discourse continuity rather than 
for modification or new information" (Olza Zubiri et al. 2002:525 [my translation]). ${ }^{19}$ Recall that in Ignaciano, $t i$ - may be omitted, constituting a sign of non-markedness.

In the rest of this section, I investigate the pragmatic correlates of the alternative ways of encoding a third-person subject in natural discourse, where the specific context of occurrence can be checked and the frequency of each type of deviation can be evaluated. Examples where ty-is used instead of the $m a$ - set are examined (6.1) and then the rare examples where the $m a$ - set is used instead of ty- (6.2 and 6.3). I show that the approaches of Gill and Olza can be integrated, and that reference tracking and transitivity account once again for the distribution of the third-person prefixes.

6.1. $t y$ - used instead of the $m a$ - set in discourse. First, the data elicited via the "Questionnaire for Transitivizing/Detransitivizing Verb Systems" (Nichols, Peterson, and Barnes 2004 and Nichols 2005) suggest discourse effects on third-person subject encoding. In the majority of sentences, tyis used on an intransitive verb and $m a-$ on its transitivized counterpart, as expected (all participants being masculine third persons). However, some examples show transitive verbs prefixed with $t y$-, as in (44b).

\begin{tabular}{|c|c|c|c|c|c|c|}
\hline$(44 a)$ & $\begin{array}{l}\text { Juan } \\
\text { Juan }\end{array}$ & $\begin{array}{l}\text { mu-em-'o } \\
\text { 3М-see-АCT }\end{array}$ & $\begin{array}{l}\text { to } \\
\text { ART.NH }\end{array}$ & $\begin{array}{l}\text { moto } \\
\text { motorbike }\end{array}$ & $\begin{array}{l}\text { ma-ye'e } \\
\text { 3M-POSS }\end{array}$ & $\begin{array}{l}m a \\
\text { ART.M }\end{array}$ \\
\hline & $\begin{array}{l}\text { Pedr } \\
\text { Pedr }\end{array}$ & & & & & \\
\hline & ‘Juan sa & w Pedro's mo & orbike'. & & & \\
\hline$(44 b)$ & ema & $t(y)$-ime-cho & to & ma-ye'e & moto & $m a$ \\
\hline & PRO.M & 3-show-ACT & ART.NH & 3M-POSS & motorbike & ART. \\
\hline
\end{tabular}

'He showed Juan his motorbike'.

Interestingly, the reverse configuration is never found in this data set: no example of an intransitive verb prefixed with a specified third-person index is attested. A plausible explanation for this deviation is that since the same virtual participants (Pedro and Juan) were suggested to the speaker for the pairs of sentences in the questionnaire, an artificial discourse line was created. The prefix ty-in (44b) would mark topic continuity, since the pronominal subject refers to a referent already introduced in the preceding sentence (given in $44 a$ ).

${ }^{19}$ El prefijo ti- es un prefijo de 'bajo perfil', un prefijo 'frío', 'discreto', no resalta, no destaca, no contrasta, sirve más a la continuidad del discurso, que a un cambio o introducción de información. 
Second, cases where a specified prefix of the $m a$ - set is substituted for by ty-are also common in natural discourse. The majority of occurrences of tyencoding the subject of a transitive verb are found in agent nominalizations without overt nominalizer. In (45), the article $\tilde{n} i$ signals the embedding of the clause in an argument position and refers to the subject of the dependent verb. Indexation with ty- does not hinder reference tracking, since normal constituent order (SOV) is respected within the nominalized clause and there is no real possibility of ambiguity between the participants.

$$
\begin{array}{ccccc}
\tilde{n} i \text {-kepripo } & \tilde{n} i & \boldsymbol{t}(\boldsymbol{y}) \text {-ve-'-yo } & \text { to } & \text { ta-chuti. } \\
\text { 3M-arrive } & \text { ART.M } & \text { 3-take-ACT-FUT } & \text { ART.NH } & \text { 3NH-head } \\
\tilde{n} i \text {-yusti-k-po } & \tilde{n} i \text {-ve-'-po, } & \tilde{n} \text {-om-po } \\
\text { 3M-detach-ACT-PERF } & \text { 3M-take-ACT-PERF } & \text { 3M-carry-PERF } \\
\text { 'The one who was going to take the head (of a slaughtered bull) } \\
\text { came, he cut it, took it, and carried it away'. }
\end{array}
$$

In (46), there is no article signaling agent nominalization. However, the suffix -ri' $i$ marks an equation between 'the man' and the verb 'to transform' (see $\mathbf{2 . 2}$ above). Again, ty- is exceptionally found for a third-person subject on a transitive verb.

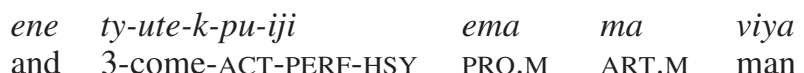

$$
\begin{aligned}
& \text { t(y)-ekie-ri-k-ri' } i, \quad \text { ma-ekie-ch-wok-po } \\
& \text { 3-transform-PLURACT-ACT-ri' } i \text { 3M-transform-ACT-PL.O-PERF }
\end{aligned}
$$

The following pair of elicited examples highlights the pragmatic difference between a regular predication (47a) and an equative construction (47b). In $(47 b)$, the first element is a pronoun referring to the subject; the second element of the equation is plausibly an agent nominalization without overt nominalizer but marked with $t y$-. In (47a), the predicate is the new information, while in $(47 b)$, it is the equation between the referent and some presupposed information that is new.
(47a)

$$
\begin{array}{lll}
\text { esu } & \text { s-itko-po } & \text { ty-aj-ri-ko } \\
\text { PRO.F } & \text { 3F-know-PERF } & \text { 3-write-PLURACT-ACT }
\end{array}
$$
'She already knows how to write'.
(47b) esu t(y)-itko-po ty-aj-ri-ko
PRO.F 3-knOw-PERF 3-write-PLURACT-ACT

'She already knows how to write'/'She is the one to already know how to write' (acceptable but weird; it would mean that no other girls know yet). 
This set of examples can be explained by the correlation between transitivity and grounding ${ }^{20}$ in discourse. The core of Hopper and Thompson's article is that "the foci of high Transitivity and low Transitivity correlate with the independent discourse notions of foregrounding and backgrounding respectively" (1980:294). In Trinitario, most predicates carrying a $t y$ - prefix for third-person subject where a specified prefix is expected (according to rules of transitivity) are found in backgrounded sections of texts. Backgrounding can be done via the equative construction or via agent nominalization without overt nominalizing suffixes. For instance, compare the two forms of the verb ve'o 'take' in (45) above, where the subject and the object are equal. ty- occurs when the event is used as a scene-setting statement to introduce a referent (it is backgrounded); $\tilde{n} i$ - is found when the same event is an action of the storyline. The scenario is the same in (46). ${ }^{21}$

The common deviations in the use of ty- on a verb on which the ma- set is normally expected can be explained by discourse factors, either the topicality of the subject or the backgrounding of the event expressed by the verb.

6.2. The $m a$ - set instead of $t y$ - on intransitive verbs in discourse. Cases of the ma- set being used instead of ty- in natural discourse are less frequent. The exception presented in this section, a specified third-person prefix on an intransitive verb, is surprising and unique in my corpus. The last predicate of (48) is an intransitive verb with a specified third-person prefix $t a$-instead of ty-.

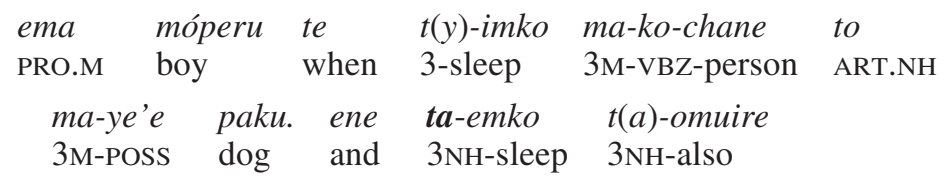

'The boy, when he is sleeping, is with his dog. And it is also sleeping'.

Specifying the subject of this clause does not seem crucial in terms of reference tracking since the referent is overtly expressed in the closest pre-

20 “. . . in any speaking situation, some parts of what is said are more relevant than others. That part of a discourse which does not immediately and crucially contribute to the speaker's goal, but which merely assists, amplifies or comments on it, is referred to as BACKGROUND. By contrast, the material which supplies the main points of the discourse is known as FOREGROUND. Linguistic features associated with the distinction between foreground and background are referred to as GROUNDING" (Hopper and Thompson 1980:280).

${ }^{21}$ This example also exemplifies the correlation of "lower transitivity" in the background with the occurrence of the pluractional -ri -re suffix. This high correlation is explained by the aspectual load of pluractionals: the more stative the process, the more probable it is that it will participate in a background situation. However, (52) shows that indexation with ty- or the $m a$ - set is independent of the presence of $-r i$. This pluractional suffix is not detransitivizing. 
ceding constituent, and since the word tomuire 'also' explicitly refers to a non-human participant (cf. $t a$-) and only two participants are given, the boy and the dog. This exception can be explained in terms of contrastive focus, i.e., "a constituent that identifies a subset within a set of contextually given alternatives" (Drubig and Schaffar 2001:1079). This idea is corroborated by the presence of the same verb being used in the previous clause with another subject and 'also', that typically carries a focalizing function.

6.3. The $m a$ - set instead of $t y$ - on transitive verbs in discourse. $k o$ denominal verbs and verbs with an indefinite object usually take $t y$ - even with a third-person object. However, a specified prefix is found instead of ty- on these verbs when their object is preverbal. Since object fronting is linked to pragmatic function, this non-standard encoding also reflects discourse effects.

Transitive ko- denominal verbs take ty- due to their low transitivity (5.3). All the exceptions have in common that the object precedes the predicate. The verb kijare 'to have as a name, to be called' takes ty-throughout the corpus, even though it has two arguments, as in (32). Only in one occurrence in my corpus does it take a specified prefix as subject, and it is also the only occurrence where the NP expressing the "name" precedes the verb kijare and its subject eto follows.

\begin{tabular}{|c|c|c|c|c|c|}
\hline eto & pjoka & to & ta-echj & $-s^{\prime} O$ & to \\
\hline PRO.NH & DEM.NH & ART.NH & $3 \mathrm{NH}-\mathrm{sp}$ & ak-ACT-APPL & ART.NH \\
\hline $\begin{array}{l}\text { anjina, } \\
\text { angina }\end{array}$ & $\begin{array}{l}\boldsymbol{t a}-k-i j a \\
3 \mathrm{NH}-\mathrm{VH}\end{array}$ & -name & $\begin{array}{l}\text { eto, } \\
\text { PRO.NH }\end{array}$ & $\begin{array}{l}\text { ene? } \\
\text { and }\end{array}$ & \\
\hline
\end{tabular}

'This one here is called angina, it is called that, right?'

Below is another example of a $k o$ - denominal verb with a specified prefix as subject (see also 36b). Again, the "normal" position of the subject and the object around the predicate is reversed. The use of the specified $m a-(\mathrm{M})$ reveals the non-coreference of the subject with the preceding pronoun eto $(\mathrm{NH})$. Since the subject is masculine, eto $(\mathrm{NH})$ must be interpreted as the object. The expected form tkoi'e in example (50) would lead to the interpretation 'it (the book) has him, José Santos Noco'. Therefore, subject prefixes are quite useful for reference tracking when the basic constituent order SVO is not respected.

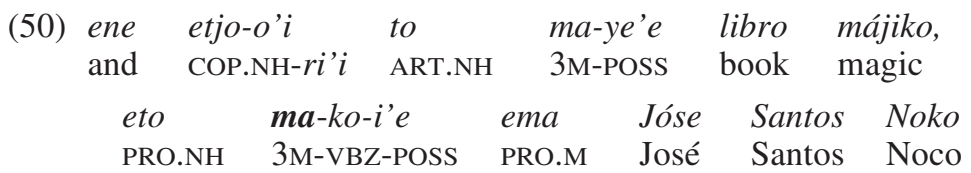

'And he had a magic book, José Santos Noco had this'. 
Object indefiniteness normally triggers ty-subject indexation on the verb (5.1). Some exceptions are found when an indefinite object precedes the verb.

(51) ta-mutu s-árami, $\quad$ ta-mut-chujcha $\mathbf{s}$-árami. 3NH-all 3F-admire 3NH-all-just 3F-admire

'She admires everything, she admires anything'.

The fact that object fronting triggers subject encoding with the $m a$ - set explains some of the cases where the specified person prefixes are systematically used.

First, it may explain the behavior of some irregular verbs presented in $\mathbf{5 . 5}$ above. These verbs are used almost systematically with the object in preverbal position. ${ }^{22}$ For instance, ou'o ouriko 'to be at, to live in' almost always takes a specified prefix for third-person subject and the locative object (often ene 'there') precedes the verb (52a). (52b) shows that the same verb can be prefixed with $t y$-, when the locative object is postposed to the verb.

$\begin{array}{llll}\text { ene } & \boldsymbol{m a} \boldsymbol{a}-(o) u-r i-k o & m a & \text { tata } \\ \text { there } & 3 \mathrm{M} \text {-be-PLURACT-ACT } & \text { ART.M } & \text { father }\end{array}$

'My father is there'.

(elicited)
ma tata ty-ou-ri-ko
ART.M father
3-be-PLURACT-ACT
te
PREP
m-peno
'My father is in my house'.
1SG-house
(elicited)

Second, object fronting can explain the unconditional regularity of thirdperson subject encoding with a specified prefix on object nominalizations without overt nominalizer. In such constructions (53a), the article that precedes the verb, while embedding the following clause in an argument position, refers to the object of the dependent clause. The NP following the dependent verb refers to the subject. In contrast, in agent nominalizations without overt nominalizer, like $(53 \mathrm{~b})$, the absence of a specified prefix indicates a normal word order: the object follows the verb and the subject precedes it (the nonhuman article to, also used here to embed the nominalization in an argument position).

\begin{tabular}{|c|c|c|c|c|}
\hline & na-kopa-ko & to & $\begin{array}{l}n \boldsymbol{n} \text {-ni-ko } \\
3 \text { PL-eat-ACT }\end{array}$ & $\begin{array}{l}\text { eno } \\
\text { PRO PL }\end{array}$ \\
\hline
\end{tabular}

'They killed it for the people to eat'.

$\begin{array}{lllll}n a-k o p a-k o & \text { to } & \boldsymbol{t}(\boldsymbol{y}) \text {-ni-ko } & \text { eno } & \text { 'chañ-ono } \\ \text { 3PL-kill-ACT } & \text { ART.NH } & \text { 3-eat-ACT } & \text { PRO.PL } & \text { person-PL }\end{array}$

'They killed the jaguar (the one that eats people)'. (elicited)

\footnotetext{
${ }^{22}$ The irregular verb jicho 'say, make' always takes a specified prefix for a third-person subject. In the majority of its occurrences, it is preceded by its object (the quoted speech) and followed by its subject (the speaker). Perhaps at some point the high frequency of the specified indexation due to constituent order triggered its extension to all cases by analogy, as in (41).
} 
Finally, the effect of constituent order on subject encoding may also explain why when two sentences follow one another in a text and share arguments, the first can be indexed as intransitive (the following object being indefinite or new) and the second as transitive (the preceding object being then definite or given). This is illustrated in (54).

$$
\begin{aligned}
& \begin{array}{lll}
\boldsymbol{t}(\boldsymbol{y}) \text {-wach-ri-ko-m-po } & \text { smoru, } & \text { chiwa, wrayu, } \\
\text { 3-pay-PLURACT-ACT-PL-PERF } & \text { pig } & \text { goat chicken }
\end{array} \\
& \text { 'poji... } \boldsymbol{t}(\boldsymbol{y}) \text {-ko-i'-om-po kwoyu, } \\
& \text { duck 3-VBZ-POSS-PL-PERF horse } \\
& \text { na-wach-ri-k-po t(a)-omuire } \\
& \text { 3PL-pay-PLURACT-ACT-PERF 3NH-also }
\end{aligned}
$$

In conclusion, all the exceptions analyzed in this section (ty-instead of the $m a$ - set described in 6.1, and the $m a$ - set instead of $t y$ - discussed in $\mathbf{6 . 2}$ and 6.3) clearly pertain to pragmatics at the information structure level, as suspected by Gill. This paper supports his intuition and adds the possible use of a specified prefix where the unspecified one is expected, and a finer analysis of the function of indexation deviations based on the detailed description of the context of utterance. Deviating third-person subject encoding is linked to discourse mechanisms like the encoding of pragmatic roles, foregrounding/ backgrounding (via the choice of a transitive vs. equative construction, or the use of nominalizations) and reference tracking. To summarize, ty- can be used on transitive verbs when no referent ambiguity arises (with basic SVO word order) to signal topic continuity or backgrounding of the event expressed by the verb. I therefore concur with Olza that $t y$ - is a low-profile prefix. The substitution of $t y$ - for the $m a$ - set is rarer: the $m a$ - set is used on bivalent verbs that normally take $t y$ - only when the object is focused in initial position, facilitating reference tracking. It is rarely used on an intransitive verb to put contrastive focus on the subject.

\section{Conclusion: a differential third-person subject-marking system.} Trinitario shows a split-intransitivity system with additional differential marking of third-person A/S on verbs. ${ }^{23}$ The distribution of subject indexes is basically dictated most of the time by rules that depend on the

\footnotetext{
${ }^{23}$ The Trinitario differential third-person marking differs in scope from many other differential third-person marking systems because, on the one hand, it is limited to subject marking and, on the other hand, it is subject to factors beyond the domain of the clause. These characteristics make it typologically distinct from coreferential markers, fourth person (Anderson and Keenan 1985:262), logophorics (Hagège 1974), switch-reference (Austin 1981:309), and obviation systems (Aissen 1997).
} 
valence of the verb and more specifically the number of third-person participants. When only the subject is a third-person participant, it is marked with the unspecified ty-. When both participants are third person, the subject is marked with an index of the $m a$ - set, semantically specified in humanness, number, and gender. The distribution of subject indexes is, however, also correlated with inherent semantic properties of a participant, like the person or the definiteness of the object, with pragmatic roles like topic and focus, and with general discourse functions like foregrounding and backgrounding. Contextual pragmatic and discourse properties are powerful enough to shortcut the general rules and lead to deviations in subject encoding. On the whole, the originality of the Trinitario indexation system lies in the fact that indexes, the basic function of which is to encode the person of the subject (reference tracking), are used more widely to encode various parameters of clause transitivity at the grammatical, semantic, and discourse levels.

This differential marking system depends on the transitivity of the predicate in discourse, a system not surprising for an Arawak language. In Arawak languages, the indexation systems may depend on transitivity seen as a scalar, non-binary notion, then displaying differential subject marking. For example, in the North Arawak language Añun, a third-person subject is indexed with $a$ - on an intransitive clause, on a clause of low transitivity, or when referring to an indeterminate subject (Patte 1992-93). Indexation in Arawak languages also frequently depends on the discourse prominence of the arguments. In some North Arawak languages, there is a special cross-referencing prefix to mark a focused $\mathrm{A} / \mathrm{S}_{\mathrm{a}}$ constituent, while person prefixes may be omitted in some other languages if $\mathrm{A} / \mathrm{S}$ a is topicalized (Aikhenvald 1995).

It is noteworthy that the differential S-marking system of Trinitario is iconic. One of the two encodings, the ma- set, constitutes, on the functional level, the "marked" element. The five elements of this set are mainly used in configurations where the grammatical roles of the two participants can easily be confused; they clarifiy the identity of one of the participants, the subject, by giving more semantic information. They are also used to express contrastive focus on $\mathrm{S}$ or when $\mathrm{O}$ is fronted. In all these situations, one participant is highlighted. In contrast, the semantically unspecified ty-is the default element. In the basic cross-referencing system, it marks third person when there is only one third person and therefore no ambiguity about its referent. It is also used when the subject is indeterminate, i.e., displays inherent low saliency. At the discourse level, it is used to signal topic continuity or backgrounding. Obviously, the functions of $t y$ - and the $m a$ - set in marking transitivity and in reference tracking are correlated with the basic feature opposing ty-and the $m a$ - set: $t y$ - is semantically unspecified, while the more specific $m a$ - set facilitates reference to a participant in a more precise and salient way. 


\section{REFERENCES}

Aikhenvald, A. 1995. Person marking and discourse in North Arawak languages. Studia Linguistica 49:152-95.

1999. The Arawak language family. The Amazonian Languages, ed. R. M. W. Dixon and A. Aikhenvald, pp. 65-106. Cambridge: Cambridge University Press.

AISSEN, J. 1997. On the syntax of obviation. Language 73:705-50.

Anderson, S., And E. Keenan. 1985. Deixis. Language Typology and Syntactic Description, vol. 3, Grammatical Categories and the Lexicon, ed. T. Shopen, pp. 259-302. Cambridge: Cambridge University Press.

Austin, P. 1981. Switch-reference in Australia. Language 57:309-34.

Crevels, M. 2002. Why speakers shift and languages die: An account of language death in Amazonian Bolivia. Current Studies on South American Languages, ed. M. Crevels et al., pp. 9-30. Leiden: CNWS.

Crevels, M., ANd P. Muysken. 2009. Lenguas de Bolivia: Presentación y antecedentes. Lenguas de Bolivia, ed. M. Crevels and P. Muysken, pp. 13-26. La Paz: Plural Editores.

DANIELSEN, S. 2007. Baure: An Arawak Language of Bolivia. Leiden: CNWS.

Drubig, H. B., AND W. SchafFar. 2001. Focus constructions. Language Typology and Language Universals: An International Handbook, vol. 2, ed. M. Haspelmath et al., pp. 1079-1104. Berlin and New York: De Gruyter.

Fabricano NoÉ, F.; J. Semo Guají; And J. Olivio. 2003. Guía del alfabeto mojeño trinitario. La Paz: Ministerio de Educación de Bolivia.

GILL, W. 1957. Conversación y gramática trinitaria. San Lorenzo de Mojos: Misión Nuevas Tribus.

1993/1970. Diccionario Trinitario-Castellano y Castellano-Trinitario. San Lorenzo de Mojos: Misión Nuevas Tribus.

HagĖGE, C. 1974. Les pronoms logophoriques. Bulletin de la Société de Linguistique de Paris 69:287-310.

$\rightarrow$ HopPeR, P., AND S. THOMPSON. 1980. Transitivity in grammar and discourse. Language 56:25199.

IbáÑez Noza, E.; P. Fabricano NoÉ; M. GuajI NoÉ, C. Guaji Jare; B. Guaji Jare; And N. Yuco Parada. 2007. Gramática Mojeña Trinitaria. Trinidad, Beni: Centro Social y Comunitario "Ipeno Imutu," Cabildo Indigenal de Trinidad.

MARBÁn, P. 1701. Arte de la lengua Moxa, con su Vocabulario, y Cathecismo. Lima.

MaYeR, M. 1969. Frog, Where Are You? New York: Dial Books for Young Readers.

MERLAN, F. 1985. Split intransitivity: Functional oppositions in intransitive inflection. Grammar Inside and Outside the Clause, ed. J. Nichols and A. Woodbury, pp. 324-62. Cambridge: Cambridge University Press.

NichOLS, J. 2005/1999. Lexical valence typology project: Instructions for elicitation of causative-noncausative verb pairs. Ms.

$\rightarrow$ Nichols, J.; D. Peterson; AND J. BARnes. 2004. Transitivizing and detransitivizing languages. Linguistic Typology 8:149-211.

Olzza Zubiri, J.; C. Nuni De Chapi; And J. Tube. 2002. Gramática Moja Ignaciana. Caracas: Universidad Católica Andrés Bello.

Otт, W., AND R. Oтт. 1967a. Ignaciano. Bolivian Indian Grammars, vol. 1, ed. E. Matteson, pp. 85-137. Norman: Summer Institute of Linguistics and University of Oklahoma.

. 1967b. Phonemes of the Ignaciano language. Linguistics 35:56-60.

1983. Diccionario ignaciano y castellano, con apuntes gramáticales. Cochabamba: Instituto Lingüístico de Verano.

Patte, M.-F. 1992-93. Variations d'actance en añun. Modèles linguistiques 14:2. 
$\rightarrow$ PAYne, D. 1987. Some morphological elements of Maipuran Arawakan : Agreement affixes and the genitive construction. Language Sciences 9:57-75.

Rose, F. 2008. The word-prosodic system of Mojeño Trinitario and pervasive vowel deletion. Paper presented at A Estrutura de Línguas Amazônicas: Fonologia e Gramática II, Recife, November 27, 2008.

2011. Dialectes en danger: Les derniers locuteurs du mojeño javeriano de Bolivie. Faits de Langues, vols. 35-36, ed. C. Grinevald and M. Bert, pp. 255-64. Paris: Ophrys.

. Forthcoming. Mojeño Trinitario. Lenguas de Bolivia, vol. 3, Oriente, ed. M. Crevels and P. Muysken. La Paz: Plural Editores.

SAIto, A. 2005. Las misiones y la administración del documento: El caso de Mojos, siglos XVIII-XX. Usos del documento y cambios sociales en la historia de Bolivia, Senri Ethnological Studies 68:27-72.

SalvatierRa, C. 2005. Gramática trinitaria. Cochabamba: Universidad Mayor San Simon. 